\title{
A habitação do Logos: um estudo de João 4,14 à luz do conceito veterotestamentário do tabernáculo israelita
}

\author{
Orientador: Isidoro Mazzarolo \\ Mestrando: Fabio Ramirez dos Santos Neves Ferreira \\ Área de Concentração: Teologia Bíblica
}

Linha de Pesquisa: Análise e Interpretação de Textos do Antigo e Novo Testamento

A presente dissertação aborda o estudo de João 1,14, especificamente no

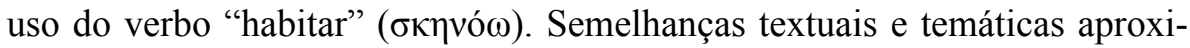
mam o texto estudado das tradições veterotestamentárias acerca do tabernáculo israelita. O verbo skenoô e as variações provindas de sua raiz, são usados pela LXX na maioria dos textos em que o tabernáculo está em questão. Desta forma, é pretendido pela pesquisa analisar a possibilidade do texto joanino ter a habitação de Deus no tabernáculo (eg. Ex 25,8) como base para a habitação do Logos entre os homens. Para alcançar tal objetivo, será feita uma análise comparativa entre o texto de João 1,14 com as declarações acerca do tabernáculo presentes no Antigo Testamento.

Palavras-chave: Teologia Bíblica. Evangelhos. Logos. 